\title{
Üreticilerin Bakış Açısından Coğrafi İşaretli Bir Yiyecek: Beypazarı Kurusunun Değerlendirilmesi
}

\author{
Emircan YILMAZ*, Cihan CANBOLAT**, Zuhal ÇILIINGİR ÜK***
}

Öz

Bir yöreye özgü olan ürünlerin ayırt edici özelliklerinin korunup, gelecek nesillere aktarılmasını amaçlayan coğrafi işaretli ürünler ekonomik kalkınma ve kültürel mirasın tanıtılması konularında bölge açısından önemli rol oynamaktadır. Türkiye'de coğrafi işaretli ürün sayısı gün geçtikçe artış göstermektedir. 2020 yılı Temmuz ayı itibari ile yenilebilir ve içilebilir gıda türünde coğrafi işaret tesciline sahip ürün sayısı 367 olmakla beraber başvuru sürecinde olan birçok yöresel ürün bulunmaktadır. Ankara ili ise 8 adet coğrafi işaretli ürüne sahiptir. Yöresel lezzetlerin coğrafi işaret tesciline sahip olması, bölge kültürlerinin devamlılığını sağlarken, özellikle kırsal turizmin gelişmesi açısından önemli bir araç olarak kullanılabilmektedir. Ankara ilinin ilçesi olan Beypazarı'nın sahip olduğu coğrafi işaretli bir ürün olan Beypazarı Kurusu, köklü bir yöresel geçmişe sahiptir. Bu çalışmanın amacl, gastronomik bir ürün olarak ele alınan coğrafi işaret tescil belgesine sahip Beypazarı Kurusu üreticilerinin perspektifinden meslek ve sektör bağlamında sürdürülebilirliğini değerlendirmek ve yerel ekonomisine katkısını ortaya koymaktır.

Anahtar Kelimeler: Gastronomi Turizmi, Beypazarı Kurusu, Turizm, Coğrafi İşaret, Ankara.

\section{An Evaluation on Beypazarı Kuru -A Local Food with Geographical Indication- from Producer's Perspective}

\section{Abstract}

Products with geographical indications, which aim to preserve the distinctive features of products that are specific to a region and transfer them to future generations, play an important role in terms of economic development and promotion of cultural heritage. The number of products with geographical indications in Turkey is increasing day by day. As of July 2020, the number of products with geographical indication registration in food section is 367 , but there are many local products in the application

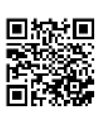

\section{Özgün Araştırma Makalesi (Original Research Article) \\ Geliş/Received: 17.05 .2019 \\ Kabul/Accepted: 28.07.2020 \\ DOI: $h$ ttps://dx.doi.org/10.17336/igusbd.565312}

*Yüksek Lisans Öğrencisi, Ondokuz Mayıs Üniversitesi, Sosyal Bilimler Enstitüsü, Turizm

İșletmeciliği Bölümü, Samsun, Türkiye, E-posta: emircanyilmaz37@gmail.com

ORCID https://orcid.org/0000-0002-4099-9782

${ }^{*}$ Arş. Gör., Ondokuz Mayıs Üniversitesi, Turizm Fakültesi, Gastronomi ve Mutfak Sanatları Bölümü, Samsun, Türkiye, E-posta: cihan.canbolat@omu.edu.tr ORCID https://orcid.org/0000-0002-1705$\underline{7025}$

${ }_{* * *}$ Dr. Öğr. Üyesi, Ondokuz Mayıs Üniversitesi, Turizm Fakültesi, Turizm İșletmeciliği Bölümü, Samsun, Türkiye, E-posta: zuhal.cilingir@omu.edu.tr ORCID https://orcid.org/0000-0002-3271$\underline{7765}$ 
process. Ankara province has eight products in this manner. While the regional tastes have geographical indication registration, they can be used as an important tool for the development of rural tourism, while ensuring the permanence of the regional cultures. Beypazarı Kuru, which has a geographical indication is the product of Beypazarı (the district of Ankara province), has a long-established local background. The aim of this study is to evaluate its sustainability in the context of profession and sector and to show its contribution to the local economy from the perspective of the producers of Beypazarı Kuru - a gastronomic product.

Keywords: Gastronomy Tourism, Beypazarı Kuru, Tourism, Geographical Indication, Ankara.

\section{Giriş}

Dünyada son zamanlarda ülke ekonomisine katkı sağlayan sektörler sıralamasında turizm sektörü de kendine yer bulmaktadır. Turizm sektörü içerisinde, gastronomi turizmi de son yllarda büyük revaç görmektedir. Bu sebeple, yörelere, bölgelere veya bir ülkeye ait olup turistik değer taşıyan yöresel lezzetlerin korunması amacı ile coğrafi işaret tescili verilmeye başlanmıştır (Orhan, 2010, s. 243).

Bir ürünün yöresel veya bölgesel bağlantısını ifade etmede coğrafi işaretler kullanılmaktadır. Coğrafi işaret tescili, hem bir yörenin değerlerinin korunmasına hizmet etmekte hem de yöre ekonomisine katkı sağlamaktadır (Dayısoylu, Yörükoğlu \& Ançel, 2017, s. 80). Tüketicilerin son yıllarda özellikle yöresel ürünlere olan ilgilerinin artması, bir yöreye özgü olan ürünlerin coğrafi ișaret ile koruma altına alınarak, üretiminden satışına kadar geçen süreçte belirli bir standarda sahip olmalarını gerektirmektedir.

Türkiye'nin geçmişten günümüze birçok medeniyete ev sahipliği yapmış olması, kültürel zenginliğinin sebebi olarak gösterilebilir. Bir yörenin yemek kültürü ve genel kültürü birbirlerini etkilemekte ve bu iki kültürün etkileşimi gastronomi turizminin gelişmesine katkı sağlamaktadır (Töre Başat, Sandıkçı \& Çelik, 2017, s. 65). Birçok farklı bölgeye sahip olan Türkiye'nin her bölgesinde yöreye özgü olan çeșitli lezzetler bulunmaktadır. Bu yöresel lezzetlerden 367 tanesi coğrafi işaret tesciline sahiptir. Aynı zamanda coğrafi işaret tescili için Türk Patent Enstitüsüne (TPE) yapılmış ve henüz süreci tamamlanmamış çok sayıda başvuru da bulunmaktadır.

Çalışmanın amacı, coğrafi işaret tescil belgesine sahip gastronomik bir ürün olan Beypazarı Kurusunun, üreticileri nezdinde bugününü ve geleceğini değerlendirebilmektir. $\mathrm{Bu}$ amaçla, çalışmada öncelikle coğrafi işaret kavramı tanımlanacak, tarihçesi, unsurları, türleri, işlevleri, kullanımı ve denetimi anlatılarak, gastronomi turizmine değinilecektir. Sonrasında, konuya ilişkin literatüre yer verilerek, coğrafi işarete sahip gastronomik bir ürün olan Beypazarı Kurusu nitel bir araștırma ile meslek ve sektör bağlamında değerlendirilecektir.

\section{Coğrafi İşaretin Kavramsal Çerçevesi 1.1. Coğrafi İşaretin Tanımlanması}

Dünyada yaşamakta olan her toplumun kendine özgü kültürleri ve bu kültürden esinlenerek ortaya çıkan ürünleri bulunmaktadır. Coğrafi işaretler yöresel bir ürünün, bir ülke, yöre ya da bölge ile arasında bağlantıyı ifade etmek için kullanılmaktadır (Yenipınar, Köşker \& Karacaoğlu, 2014, s. 14). Coğrafi işaret, belirli bir geçmişe sahip ve yöreye özgü niteliklere sahip ürünlere verilmektedir. Bu işarete sahip olan ürünler, ortaya çıktıkları yerlerin isimlerinden oluşmaktadır (Norrsjö, 2004, s. 7). Ilıcalı'ya (2005, s. 2) göre coğrafi işaret, belirli bir yörede üretilen ürünü tanımlayan, ürünün kalitesini ve ayırt edici 
özellikleri itibariyle coğrafi kaynağına atfedilen ve bir bölgeyi işaret gösteren sınai mülkiyet hakkıdır. Yöresel ürünlerin korunması için ortaya çıkan coğrafi işaretler, Dünya Ticaret Örgütü'ne göre "Belirgin bir niteliği, ünü veya diğer özellikleri yönünden kökeninin bulunduğu yöre, alan, bölge ya da ülkeyle özdeşleşmiş bir ürünü gösteren işaretlerdir" (Altuntaş \&Gülçubuk, 2014, s. 74-75). Bir başka ifade ile coğrafi işaretler, bir ürünün kaynağını göstermektedir (Şahin \& Meral, 2012, s. 89).

Coğrafi işaretler, bir topluma özgü olan ürünlerin belirlemesi ve bu ürünlerin korunarak devamlılı̆̆ının sağlanması için uygulanmaktadır (Karakulak, 2016, s. 6). Coğrafi işaret, üretilen bir ürünün yöresel olarak önem kazanmasıyla birlikte, ürünün ayırt edilmesi için de kullanılmaktadır (Kan, 2011, s. 19). Coğrafi işaret, herhangi bir üründen farklı özellikler ile ön plana çıkan ve bulunduğu yer ile özdeşleşen ürünlere verilen işarettir. Coğrafi işaretler içerisinde tarım, maden, el sanatları, yöresel yiyecekler ve sanayi ürünlerini barındırmaktadır (Oraman, 2015, s. 76).

Coğrafi işaretli ürünler, meydana geldikleri bölgelerin adları ile birlikte anılmaktadırlar. Bu bölgeler, bir köy, kasaba ya da şehir olabilmektedir. Coğrafi işaretli ürünler yetiştikleri bölgeye özgü olduklarından bașka bölgelerde üretilememektedir (Çakaloğlu, 2015, s. 15). Türkiye'den bölge isimleri ile anılan coğrafi işaretli ürünlere, Çorum Leblebisi, Antep Fıstığı, Isparta Halısı, Beypazarı Kurusu, Adana Kebap, İnegöl Köftesi örnek olarak verilebilir. Dünya'dan ise Bordeaux Şarabı, Roquefort Peyniri, Scotch Viskisi gibi örnekler vermek mümkündür (Tepe, 2008, s. 5).

Coğrafi işaretlerin kullanılması, bir bölgeye ya da yöreye özgü olan ürünlerin belirlenen koşullara göre üretilmesi ile mümkün olmaktadır (Zuluğ, 2010, s. 52). Bir ürünün coğrafi işarete sahip olması, ürünün satın alınmasını arttırarak üreticilerine de fayda sağlamaktadır (Çakaloğlu, 2015, s. 16). Coğrafi işaretin temel amacı, bir bölgeye has olan yöresel ürünleri koruyarak ve devamlılığını sağlayarak belgelendirmektir (Karakulak, 2016, s. 7). Coğrafi işaretin bir başka amacı ise, bir yörede üretim yapan üreticiyi korumak ve tüketicilere de kaliteli ürünler sunulmasını sağlamaktır (Tanrıkulu, 2011, s. 6).

Coğrafi işaretler, bir ürünün marka, patent gibi haklarının sadece tek bir üretici için değil, ürünün üretildiği belirli bir bölgede üretim yapan tüm üreticiler adına korunmasını sağlamaktadır. Bu durumdan coğrafi işaretlerin, bir ürün için belirli bir kişiye özel olarak hak sağlamadığı, aksine hak sahipliğini bütün bir yöreye ve ülkeye verdiği anlaşılmaktadır (Akın, 2006, s. 3). Koruma altına alınan bir coğrafi işaretli ürünün, hak sahibi olmayan kişiler tarafından kullanılması, taklit edilmesi ve tüketicilerini yanıltacak bilgilerin aktarılması gibi durumlar yasal değildir (Akın, 2006, s. 4-5).

Türk Patent Enstitüsü tarafından hazırlanan ve 2015-2018 yılları arasını kapsayan "Ulusal Coğrafi İşaret Strateji Belgesi ve Eylem Planı" ile "Ulusal Coğrafi İşaret Strateji Belgesi ve Eylem Planı" içerisinde ortaya konan, Türkiye'nin coğrafi işaretler ile ilgili SWOT analizi Tablo 1'de görülmektedir. 


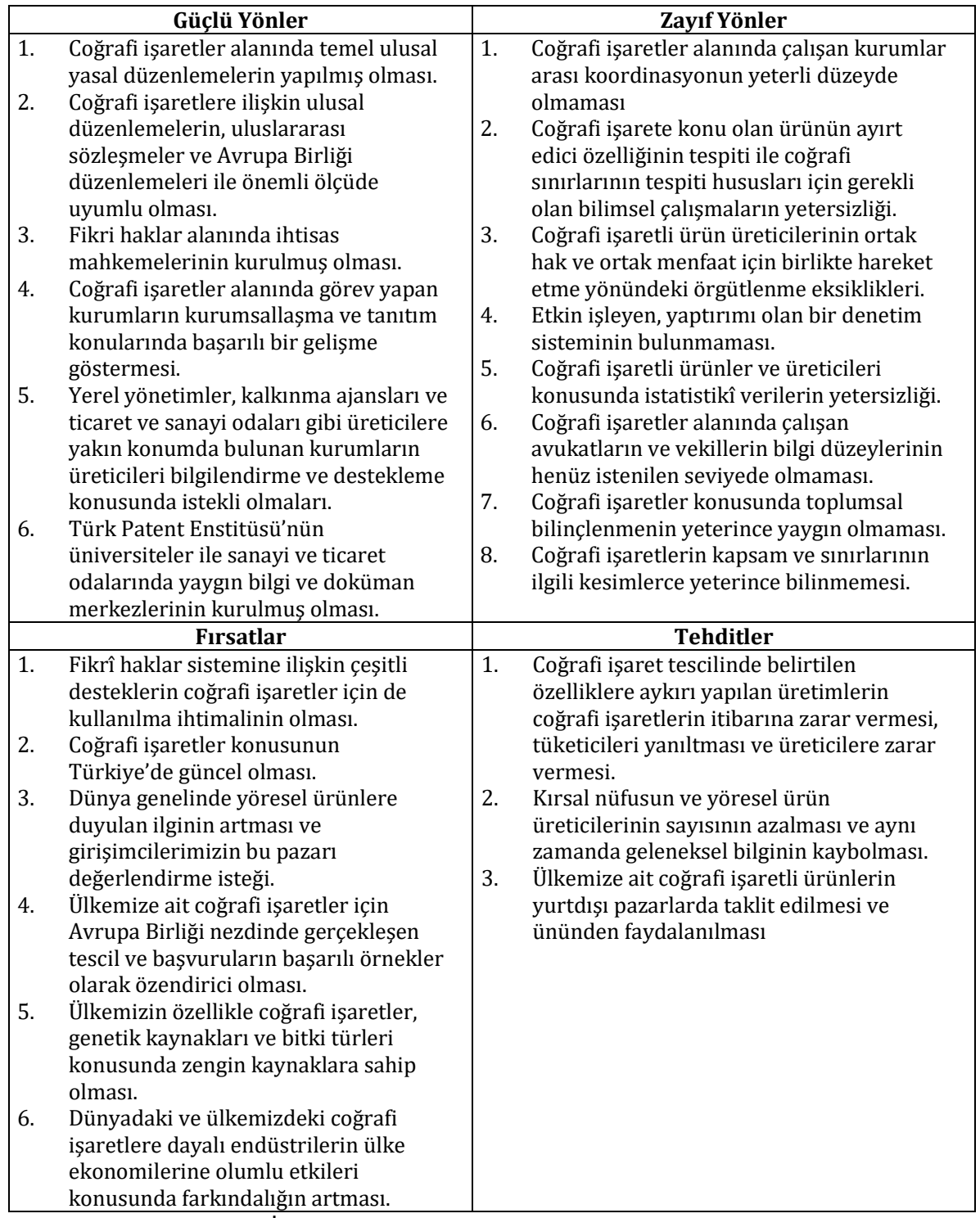

Tablo 1: Ulusal Coğrafi İşaret Strateji Belgesi ve Eylem Planı'na Göre Türkiye'nin SWOT Analizi

Kaynak: TPE, 2018.

Tablo 1'de görüldüğü gibi Türkiye'nin coğrafi işaretler bağlamında birçok güçlü yanı ve fırsatı olmasına rağmen, bir o kadar da zayıf yönü ve tehdit unsuru söz konusudur. Zayıf yönlerin ve tehditlerin, bir an önce coğrafi işaretli ürünlerle ilgili olan kurum TPE tarafından çalıșmalar yapılarak azaltılması beklenmektedir. Özellikle coğrafi işaretli ürünlerin düzenli bir işleyișe sahip olması ve bu işleyişin takibine yönelik denetim sisteminin kurulması hususları büyük önem arz etmektedir. 


\subsection{Coğrafi İşaret Tarihçesi}

Coğrafi işaretler, dünyada geçmiși en eskiye uzanan ayırt edici işaretlerdir. Bunlar, belli bir yöreye özgü olan ve coğrafi kökeninden dolayı önemli hale gelen ürünleri ayırt etmek için kullanılmaktadır (Kan \&Gülçubuk, 2008, s. 59). Coğrafi işaretlerin tarihsel süreçte ilk olarak ortaya çıkış sebebi, ürünlerin üretildikleri yöreleri gösteren kaynaklar olmasıdır (İloğlu, 2014, s. 9).

Coğrafi ișaretlerin ortaya çıkışının nasıl olduğu tam olarak bilinmemektedir. Bazı görüşlere göre; ilk kez 12.yüzyılda Orta Avrupa ve İngiltere'deki dokumacılar ve koloniler tarafından ürünlerin ticaretinde coğrafi kökenleriyle arasındaki bağlantıyı belirleyebilmek ve ürünleri etiketleyebilmek için kullandıkları ileri sürülmektedir (Rangnekar, 2003, s. 11). Eski Mısır'da ise ürünlerin yerlerini ve kalitelerini tanımlamak için coğrafi işaretlerin kullandıkları belirtilmektedir (Van De Kop \&Sautier, 2006, s. 21). Coğrafi işaretlere örnek verilebilecek ürünlerin başında Parmesan peyniri gelmektedir. İtalya'da 1612 yılında yayınlanan bir kanun ile korunmaya alınan Parmesan peynirinin sadece Parma yöresinde üretilebileceği belirlenmiştir (Akın, 2006, s. 4). Coğrafi işaretlere ayrıca Hollanda'dan Edam peyniri, Fransa'dan Comte ve Gravyer peynirleri de örnek gösterilebilir (Van De Kop \&Sautier, 2006, s. 21).

Bir bölgeye has olan ürünleri koruma girişimlerin geçmişi 19.yüzyılın sonlarına dayanmaktadır. Söz konusu ürünler uluslararası alanda ilk olarak "Sınai Mülkiyetin Korunması Hakkında Paris Sözleşmesi” ile korunma altına alınmıştır (Menapace, 2010, s. 8). Paris Sözleșmesi'nden sonra coğrafi işaretler ile ilgili olarak Madrid ve Lizbon Sözleşmeleri de yürürlüğe girmiştir (İloğlu, 2014, s. 11). Bu sözleşmenin dişında olan Amerika Birleșik Devletleri'nde ise 1946 yılında markaları garanti altına almak için Lanham Kanunu çıkarılmıștır (Gündoğdu, 2006, s. 8).

Türkiye'de coğrafi işaret tescillemesi konusundaki ilk girişim 1871'de düzenlenen "Alameti Farika Nizamnamesi"dir. 1930 yılında imzalanan T.C Başvekâlet Muamelat Müdürlüğü'nün yazısında, sahte olan menşelerin meni hakkında Madrid Sözleşmesi'ndeki 1925 tarihli La Haye metninin kabul edilmesinin uygun olacağı bildirilmiştir (Ilgaz, 1995, s. 136).Ancak coğrafi işaretleme günümüzdeki şeklini 1995 yllında kabul edilen "555 sayılı Kanun Hükmünde Kararname" ile almıștır. Bu düzenlemeden sonra Türk Patent Enstitüsü tescil haklarıyla ilgilenen resmi kurum haline gelmiştir (Şahin, 2013, s. 25).

\subsection{Coğrafi İşaret Unsurları}

Bir işaretin coğrafi bir işaret olarak temsil edilebilmesi için ürün, belirli bir coğrafya, ișaret, ürünün ayırt edici özelliğe sahip olması ve ürünün ayırt edici özellikleriyle coğrafyası arasında bağlantı bulunması gibi unsurlara sahip olması gerekmektedir (Erol, 2014, s. 26). Bu unsurlar aşağıda sırasıyla açıklanacaktır.

Ürün: Coğrafi işaretlerin başlıca amaçlarından biri belli bir yöreye özgü olan ürünü, benzeri olan ürünlerden ayırmak ve farklılaştırılmasını sağlamaktır (Tepe, 2008, s. 9). Uluslararası sözleşmeler incelendiğinde, ürün kavramı ile ilgili herhangi bir ayrım yapılmadığı, ürünlerin genel olarak kategoriler şeklinde ifade edildiği görülmektedir (Erol, 2014, s. 26). Avrupa Birliği hukukunda da coğrafi işarete ilişkin ürünler ile ilgili kategorilerin oluşturulduğu ve söz konusu ürünlerin korunmasının oluşturulan kategoriler ile sınırlı olduğu görülmektedir (Kan, 2011, s. 20). Türkiye'de coğrafi işaretlerin belirlenmesi ve yasalaştırılmasında uluslararası yapılan anlaşmalar ve Avrupa Birliği mevzuatı dikkate alındığından, ürün kavramındaki yaklaşımlar 555 Sayılı Coğrafi İşaretler Kanun Hükmünde Kararname'de hissedilmektedir (Gündoğdu, 2005, s. 228). ‘555 Sayılı Coğ. İș. KHK'nın 1. Maddesindeki “Bu Kanun Hükmünde Kararname, doğal ürünler, tarım, maden ve el sanatları ürünleri ile sanayi ürünlerinden bu Kanun Hükmünde 
Kararnamede yer alan tanımlara ve koşullara uygun her türlü ürünün coğrafi işaretlerle korunmasına ilişkin kuralları ve şartları kapsar" hükmüyle kategoriler oluşturulmuştur (Yürekli, 2015, s. 48). Bu hükümler doğrultusunda ülkemizde coğrafi işarete sahip olabilecek ürünler, doğal ürünler, tarım, maden, el sanatları ve sanayi ürünleri olarak kategorize edilebilmektedir (Gündoğdu, 2005, s. 228).

Belirli Bir Coğrafya: Bir ürünün coğrafi işarete sahip olup olamayacağından bahsedebilmek için ilk olarak ürünün bir coğrafyaya sahip olması gerekmektedir (Tepe, 2008, s. 7). Madrid Sözleșmesi'nde, sözleșmeye üye olan ülkelerin ya da ülkelerde yer alan belirli bir bölgenin coğrafi alan olduğu kabul edilmiștir (Bulut, 2013, s. 20). Lizbon Sözleşmesi'nde ise bir ürünün adının mutlaka o ürünün meydana çıtığı coğrafyadan olması gerektiği kabul edilmiştir. Lizbon Sözleşmesi'nce coğrafi işaret olarak tescillenmiş ürünlere bakılarak örnek verilecek olursa, Porto şarabı ve İskoç viskisi bu örneklerin başında gelecektir (Özgür, 2011, s. 35). Türkiye'de ise “555 Sayılı KHK'nın” 3.maddesinde yer alan coğrafi işaretlerin "kökenin bulunduğu bir yöre, alan, bölge veya ülke" olarak ifade edilen coğrafya ile ürünün iç içe geçmesini gösteren işaretler olduğu belirtilmektedir (Yürekli, 2015, s. 49).

İşaret: Coğrafi işaretler bir ürünün farklılıklarını belirlemek için kullanılmaktadır. “555 Sayılı KHK'nın” madde 17/1 de belirtildiği gibi "Coğrafi işaretlerden menşe adları, sicilde belirtilen coğrafi bölgede faaliyet gösteren üreticiler tarafindan, sicilde belirtilen ürünlerin üzerlerinde veya ambalajlarında, bu ürünlerin sicilde gösterilen kalite, ün ve diğer özellikleri taşıması koşuluyla ticari olarak kullanılır" (Özcan, 2016, s. 9). Burada işaret unsuruyla ürün ile kökeninin bağlantısı olmak koşuluyla, coğrafi bir yer ismi olup olmamasına bakılmaksızın diğer ürünlerden ayırt edilen isimlerin ve işaretlerin varlığına atıfta bulunulmaktadır. Ürünlerin ait olduğu coğrafyanın adı kullanılmadan bazı semboller ile tanımlanmasına örnek olarak Paris "Eyfel Kulesi" verilebilir. Kısacası, bir ürünün kökeni ile kuvvetli bir bağ içerisinde olan semboller coğrafi işaret unsuru olarak kullanılabilmektedir. Bu duruma örnek olarak hem coğrafyayı hem de ürün ismini belirten Kayseri pastırması, Malatya kayısısı da verilebilir (Tepe, 2008, s. 12).

Ürünün Ayırt Edici Özelliğe Sahip Olması: Coğrafi işaretli ürünlerin en önemli özelliklerinden biri kendine has ayırt edici bir özelliğe sahip olmasıdır. Bu ayırt edici özelliğin oluşmasında ürünün meydana geldiği coğrafya, kültür, üretim teknikleri ve iklimin büyük rolü vardır (Tuncay, 2009, s. 10). Ürünlerin coğrafi işarete sahip olabilmeleri için karakteristik özelliklere sahip olması koşulu Paris ve Madrid Sözleşmeleri'nde aranmamıştır (Kan, 2011, s. 21). Lizbon Sözleşmesi'nde bir ürünün korunabilmesi için sözleşmenin 2/1. maddesine göre "kalitesinin ve karakteristik özelliklerinin" bulunması şartı istenmiştir. Fakat sözleşmede ürünün "kalitesi" ve "karakteristik özellikleri" gibi kavramlar açıklanmamıștır (Özgür, 2011, s. 36). Türk Hukukunda ise mahreç işaretler için "belirgin bir niteliği, ünü veya diğer özelliklere" tabi olması istenirken, menşei isimleri ile ilgili bir açıllamaya yer verilmemiștir (Kan, 2011, s. 22).

Ürünün Ayırt Edici Özellikleri ile Coğrafi Köken Arasındaki Bağlantı: Coğrafi işarete sahip olan ürünler, yetiştikleri veya meydana geldikleri yöreden dolayı, belli başlı ayırt edici özellikleri kazanarak diğer benzer ürünlerden farklılık gösterirler (Erol, 2014, s. 27). Bir yörede yetişen, oraya özgü olan coğrafi işaretli ürüne o yörenin adının verilebilmesinin en temel şartı ürün ve yöre arasındaki bağlantıdır. Bu bağlantının olması ürünün ayırt edici özelliklerini ortaya çıkarmaktadır (İloğlu, 2014, s. 8). Bir ürünün ayırt edici olmasında doğal faktörler etkili olabilmektedir. Buna örnek olarak Amasya elmasının kokusu ve aroması verilebilir (Tepe, 2008, s. 14). 


\subsection{Coğrafi İşaret Türleri}

Coğrafi işaretler Türkiye'de, menșe adı ve mahreç işareti olarak ikiye ayrılmaktadır (Dayısoylu vd., 2017, s. 81; Gündoğdu, 2005, s. 214).

Menşe Adı: Ürünlerin üretimlerinin belirlendiği coğrafi alanlarda, ürünün üretilmesi zorunlu olan coğrafi işaretlere menşe adı verilmektedir (Çalışkan \& Koç, 2012, s. 196). Menșe adını taşıyacak ürünlerin özgün niteliklerini ve farklılıklarını koruyabilmesi için başka herhangi bir coğrafi bölgede üretimi mümkün olmamaktadır (Gündeğer, 2014, s. 22). Ürünlerin nitelikleri, özellikleri ve doğal faktörleri bulundukları coğrafya ile özdeşleşmiş olmalıdır. Bu duruma en güzel örnek Türkiye'de bulunan Pamukkale Travertenidir. Dünyada sadece Türkiye'de bulunduğu için menşe işareti ile tescillenmiştir (Durusoy, 2017, s. 75). Bu tür ürünlere ayrıca Fransa şarabı, Çerkez peyniri, Anamur muzu örnek gösterilebilir. Örneklerde de görüldüğü gibi adı geçen ürünler, yetiştikleri coğrafi bölgenin özellikleri ile özdeşlemiştir (Tuncay, 2009, s. 14). Bu ürünlerin üretildikleri sınırlar dişında üretilmesi mümkün değildir. Kendi coğrafi özelliklerini taşımayan ürünlerin ayırt edici özelliği kaybolmaktadır ve bu durum ürünün özelliğini yitirmesine sebep olmaktadır (İloğlu, 2014, s. 18).

Mahreç Íşareti: Bir ürünün tescillenmesi için kullanılan mahreç işareti, ürünün üretildiği bölgedeki özelliklerinden en az birini taşıması şartıyla, özgü olduğu yöre dışında da üretilebilmesi anlamına gelmektedir (Tuncay, 2009, s. 16). Mahreç işareti ile menşe adının arasındaki en önemli fark üretim yerleridir (Yürekli, 2015, s. 47). Menşe adı ile mahreç işareti arasındaki temel farklar aşağıdaki gibi gösterilebilir (Oğuz, 2016, s. 14).

\begin{tabular}{|c|c|}
\hline Menşe Adı & Mahreç İşareti \\
\hline Belirli bir yöre, bölge ya da ülkeye has bir ürün & Belirli bir yöreye, bölgeye has bir ürün \\
\hline $\begin{array}{c}\text { Ürünün tüm niteliklerin bu yöreye has olması ve } \\
\text { yöreden kaynaklanması }\end{array}$ & $\begin{array}{c}\text { Sadece belirgin bir niteliğinin yöreden } \\
\text { kaynaklanması }\end{array}$ \\
\hline $\begin{array}{c}\text { Ürünle ilgili bütün işlemlerin belirli yörede } \\
\text { yapılması }\end{array}$ & $\begin{array}{c}\text { Ürünün üretimindeki işlemlerinden en az } \\
\text { birinin yapılması }\end{array}$ \\
\hline
\end{tabular}

Tablo 2: Menșe Adı ve Mahreç İşareti Arasındaki Temel Farklar

Kaynak: Oğuz, 2016, s. 14.

Tablo 2'de görüldüğü gibi Menșe Adı ve Mahreç işareti arasındaki en temel fark, Menşe Adına sahip olan ürünün sadece belirli bir yörede yapılması, Mahreç işaretine sahip olan ürünün ise başka bir bölgede üretiminin yapılmasıdır. Mahreç işaretli bir ürünün başka bir bölgedeki üretiminde, üretim yöntemlerinin birebir kullanılması gerekmektedir. Mahreç işaretine sahip ürünlere örnek olarak; Antep Baklavası ve Beypazarı Kurusu gösterilebilir (Taşdan, Albayrak \& Albayrak, 2014, s. 1293).

\subsection{Coğrafi İşaret İşlevleri}

Coğrafi işaretin işlevleri asli işlevler ve tali işlevler olmak üzere 2 kategoride ele alınmaktadır. Bunlardan asli işlevler ayırt etmek, coğrafi kaynak belirtmek, ürünün üretim yöntemi ile kalitesini garanti etmek ve son olarak pazarlama aracı olmak üzere 4'e ayrılmaktadır. Tali işlevler ise kendi içerisinde, yerel üretim ve kırsal kalkınmayı destekleme, geleneksel bilgi ile kültürel değerleri koruma, turizme katkıda bulunma, çevre ile biyolojik çeşitliliği koruma ve son olarak ürün taklitçiliği ile mücadele etmek olmak üzere 5 kategoride sınıflandırılabilmektedir (Oğuz, 2016, s. 14). 


\subsubsection{Coğrafi İşaretin Asli İşlevleri}

Ayırt Edicilik İşlevi: Coğrafi işaretin bu işlevi, bir ürünün benzer olan diğer ürünlerden ayırt edici özelliklerini ortaya koymaktadır (İloğlu, 2014, s. 22). Ayırt edici özelliğe sahip bir ürüne örnek verecek olursak Isparta halısı gösterilebilir. Dünyada birçok halı üretimi olmasına rağmen Isparta halısı diğer halılardan farklıdır.

Coğrafi Kaynak Belirtmek: Bir ürünün coğrafi işarete sahip olabilmesi için ilk olarak bir yöreye veya bölgeye has olması gerekmektedir (Tepe, 2008, s. 19). Coğrafi kaynağa sahip olmak coğrafi işaretin en önemli fonksiyonlarından biridir. Bu fonksiyonu olmayan bir ürünün coğrafi işarete sahip olması olanaksızdır (Özgür, 2011, s. 42).

Ürünün Üretim Yöntemi ve Kalitesini Kontrol Etmek: Coğrafi işaretler hem bir ürünün ait olduğu yöresine ilişkin bilgi vermekte hem de üretim şekli ve standartlarına sinırlandırmalar getirmektedir (Zuluğ, 2010, s. 6). Coğrafi işaretli bir ürünün, üretim yöntemleri, tüketiciye satışı ve denetimi gibi konular, alınan tescil belgesi ile standartlaştırıldığı için söz konusu ürünlerin belirlenen standartlara uygun olarak yapılması gerekmektedir (İloğlu, 2013, s. 23).

Pazarlama İşlevi: Coğrafi işarete sahip ürünler diğer ürünlerden farklı oldukları için tüketicilerin satın alma eğilimlerinde önemli bir etkiye sahiptir. Bir ürünün belirli bir yöreye özgü olması ve söz konusu yörenin ürünü ile meşhur olması, tüketicilerin bu ürüne olan yönelimlerini arttırmaktadır (Tepe, 2008, s. 21). Bu nedenle coğrafi işaretler, hem yörelerin hem de işletmelerin pazarlama faaliyetlerini etkileyen önemli araçlardan biridir (İloğlu, 2014, s. 23).

\subsubsection{Coğrafi İşaretin Tali İşlevleri}

Yerel Üretim ve Kırsal Kalkınmayı Destekleme: Coğrafi işaretler bir yörenin veya bölgenin kalkınması için ekonomik bir araç olarak kullanılabilmektedir (Tepe, 2008, s. 23). Coğrafi işaretli ürünlerin kaliteli olması ve bir yöreye özgü olarak farklılık göstermesi hem üreticilerin hem de tüketicilerin ürüne yönelik ilgilerini artırmaktadır. Bu sebeple coğrafi işaretlerin kırsal kalkınmaya önemli derecede etkileri bulunmaktadır (Özgür, 2011, s. 45).

Geleneksel Bilgi ve Kültürel Değerleri Koruma: Bir bölgeye ait olan yöresel ürünlerin üretim metotlarında zaman içerisinde değişikliklere gidilmesi ve ürün çeşitlendirmeleri yapılması standartlaşmayı arttırmaktadır. Standartlaşma yöresel ürünlerin geleneksel üretim aşamalarını tehdit etmektedir. Yöresel ürünlerin özgünlügünü koruyabilmesi için etkin bir koruma yöntemi izlenerek üretim metotlarındaki standartlaşmanın azaltılması gerekmektedir (İloğlu, 2014, s. 24). Coğrafi işaret tescili bir ürünün gelecekteki nesillere değişime uğramadan aktarılmasına firsat vermektedir. Bu şekilde de gelecekte kültürel değerlerin korunması sağlanabilmektedir (Tepe, 2008, s. 25).

Turizme Katkıda Bulunma: Coğrafi işaretli ürünlerin turizm içerisinde özellikle gastronomi turizmine etkisi oldukça yüksektir. Söz gelimi, kırsal bir bölgede bulunan bir yörenin coğrafi işarete sahip olan gastronomik ürününün tanıtımlarının başarılı bir şekilde yapılması bölge turizmine dolayısıyla genel olarak ülke turizmine katkı sağlayacaktır (Tepe, 2008, s. 26).

Çevre ve Biyolojik Çeşitliliği Koruma: Coğrafi işaretler bir bölgede sadece üretimi teşvik etmekle kalmaz, bulunduğu çevreyi ve biyolojik çeşitliliği koruyarak, gelecekte yaşayacak olan nesillere aktarır (Özgür, 2011, s. 56).

Ürün Taklitçiliği ile Mücadele Etme: Bir yöreye has olan ürünlerin koruma altına alınmaması o ürünün taklit edilmesine neden olur. Coğrafi işaretler ürünleri koruma altına alırken hem üreticileri hem de tüketicileri koruma altına almış olur. Ayrıca coğrafi 
işarete sahip olan bir ürünün koruma altına alınması, başka kimseler tarafından kullanılmasının da önüne geçilmesi demektir (Tepe, 2008, s. 29).

\subsection{Coğrafi İşaret Kullanımı ve Denetimi}

Türkiye'de coğrafi işaretlerin tescilini Türk Patent Enstitüsü sağlamaktadır. Coğrafi işaret tescili, ürünün ayırt edici farklı özelliklerini belirleyen, üretim yöntemlerini açıklayan, ürünün üretim alanı için sınırlarını çizen ve denetimlerin nasıl gerçekleştiğini gösteren bilgilerin kaydedilerek korunmasını sağlayan bir işlemdir (İloğlu, 2014, s. 26).

Coğrafi İșaret Kullanımı: Türkiye'de coğrafi ișaretler sadece “555 Sayılı KHK'da” belirtilen şartları taşıyan ürünler üzerinde kullanılmaktadır. Madde 17’ye göre menşe adları, yörede üretim yapan üreticiler tarafından, ürünlerin üzerinde kalite ve diğer çeşitli özellikleri taşıması şartı ile kullanılabilir. Menşe adının yöre coğrafyasına sıkı sıkıya bağlı olması, bu bölgede üretim yapan üreticiler tarafından kullanılabilecek olmasını ifade etmektedir (Tuncay, 2009, s. 53). Mahreç işaretlerinin kullanımında ise ürünün üretiminde, sicilde belirtilen yöre özelliklerinden en az birini taşıması şartı aranmaktadır (Coşkun, 2001, s. 119).

Coğrafi İşaret Denetimi: 21. yüzyllda tüketicilerin tüketim bilincinde artış gözlemlenmektedir. Tüketiciler satın aldıkları ürünleri sadece tüketmekle kalmayıp bu ürünün hangi şartlar ve koşullar altında üretildiğine de önem vermektedirler (İloğlu, 2014, s. 27). Coğrafi işaretli ürünler söz konusu olduğunda, bu ürünlerin denetiminin nasıl ve kim tarafından yapılacağı sorusu akıllara gelmektedir. Coğrafi işaretlerin denetiminin nasıl olacağı, “555 Sayılı Coğ. İş. KHK'nın 20. maddesinde yer almaktadır. Bu maddeye göre, coğrafi işareti tescil ettirenler, örneğin belediyeler, dernek vb., ürünün gerekli kontrollerini yaparak denetimleri gerçekleștirmekle yükümlüdürler (Tuncay, 2009, s. 56). Denetimi yapmakla yükümlü olan kurumlar veya kuruluşlar, coğrafi işarete sahip olan ürünün, sicilde belirtilen şartları tamamen taşıyıp taşımadığını tarafsız bir şekilde kontrol etmelidirler (Ilıcalı, 2005, s. 38). Aynı Yönetmeliğin 14. maddesinde denetime ait raporların 10 yılda bir Enstitü’ye sunulmasının uygun görüldügünden bahsedilmektedir (Coșkun, 2001, s. 120).

\section{Literatür İncelemesi}

Coğrafi işaretli ürünleri turizm bağlamında ele alan, bölgesel ve ulusal ekonomiye katkısını inceleyen literatüre yansıdı̆̆ı kadarıyla sınırlı sayıda çalışmaya rastlanmaktadır. Mercan \& Üzülmez (2014) çalışmalarında kurum ve kuruluş temsilcilerinin coğrafi işaretli ürünlerin yöreye turist çekerek, yöredeki turizmin gelişimine katkı sağlayabileceği yönünde görüş bildirdiklerini ileri sürmüşlerdir. Çalışmada katılımcılar, Çanakkale ilinin turizm gelirlerine katkısının henüz bașlangıç aşamasında olduğunu, fakat ilde bulunan diğer turizm aktiviteleri ile coğrafi işaretli ürünlerin birlikte kullanılması gerektiği konusunda hem fikir olduklarını belirtmişlerdir.

Meral \& Şahin (2013) çalışmalarında, araştırmaya katılan tüketicilerin \%97,4'ünün coğrafi işaretli ürünleri tükettikleri sonucuna ulaşmışlardır. Meral (2013) çalışmasında da benzer şekilde araştırmaya katılanların \%97,4'ünün coğrafi işarete sahip olan ürünleri tükettiklerini ileri sürmüştür. Töre vd. (2017), yöresel ürünlerin tanıtılması, satışı ve tüketicilere ulaştırılmasının bir diğer anlatımla yöresel ürünlere yönelik pazarlama faaliyetlerinin başarısının ürünün varlığını koruması açısından çok önemli olduğunu belirtmişlerdir. Zuluğ (2010) araştırmasında, tüketicilere coğrafi işareti ürünler ile ilgili sorular yöneltmiştir. Tüketicilerin \%47'si ürünleri bildiğini fakat coğrafi işarete sahip olduğunu bilmediğini belirtirken, \%30’u coğrafi işaretli ürünler hakkında bilgi sahibi olmadıklarını ifade etmişlerdir. Kaya \& Şahin (2018) çalışmalarında araştırmaya 
katılan 15 kişiden 9'unun Adana kebabın coğrafi işaret ile tescillendiğini bildiklerini belirtmişlerdir. Suna \& Uçuk (2018) çalışmalarında, mutfak alanında eğitim gören öğrencilerin, coğrafi işaret ile tescillenmiş bir ürünün yöreye gastronomik bir kimlik kazandırmasına yönelik görüşlerinin yüksek düzeyde olduğunu ifade etmektedirler.

Acar (2018) Türkiye'de en fazla coğrafi işarete sahip olan illerin (Şanlıurfa 2 menşe adı ve 17 mahreç işareti, Gaziantep 1 menşe adı ve 16 mahreç işareti, İzmir 7 menşe adı ve 9 mahreç işareti) turizm açısından hızla gelişim gösterdiğini belirtmektedir. Karakulak (2016) ise, bir ilin coğrafi işaretli ürüne sahip olmasının gastronomik amaçlı ziyaretleri artıracağına yönelik soruya, katılımcıların çoğunluğunun kesinlikle katıldıklarını ifade etmektedir.

Oğuz (2016) çalışmasında, Siirt'e gelen turistlerin \%86’sının coğrafi işaretli ürünlerin turizme katkısı olduğu yönünde görüş bildirdiklerini ileri sürmektedir. Kan (2011) araștırmasında, Akșehir Kirazı üreticilerinin \%85,71'inin coğrafi ișaret tescilinin yöreye katkısının olabileceğini söylediklerini ifade etmiştir. Arıkan (2017) çalışmasında, üreticilerin \%72'sinin coğrafi işaretin üreticilere katkı sağlayacağı yönünde görüş bildirdiklerini belirtmektedir. Ayrıca üreticilerin \%78,7'sinin coğrafi işaretin bölge gelişiminde katkı sağlayacağını düşündüklerini ifade etmektedir. Özcan (2016) ise çalışmasında, coğrafi işaret hakkında işletmelerin \%60'ının bilgisinin olduğu sonucuna ulaşmıștır.

Coğrafi işaret çalışmaları arasında, çalıșmada olduğu gibi ürün olarak Beypazarı Kurusuna odaklanan çalışmalara da rastlanmaktadır. Taşdan vd. (2014), coğrafi işarete sahip olan Beypazarı Kurusu ve Çubuk Turşusu üretimi yapan işletmelerle görüşmeler yapmışlardır. Araştırmacılar, ankete katılan işletmecilerin \%70'inin Beypazarı Kurusunun coğrafi işarete sahip olduğunu bildiklerini, Çubuk turșusunda ise bu oranın \%30'un altında olduğunu belirtmişlerdir. Benzer şekilde Tuna \& Özyurt (2018)'e göre, Ankara'nın en çok bilinen gastronomik ürünü Beypazarı Kurusudur. Konu ile ilgili çalışmalar genel olarak değerlendirildiğinde, coğrafi işaretli ürünlerin bölge ekonomisine ve bölgenin tanıtımına yönelik olumlu katkıları olduğu ileri sürülebilir.

\section{Gastronomi Turizmi}

Gastronomi, Yunanca gaster (mide) ile nomas (yasa) sözcüklerinin bir araya gelmesiyle oluşmuştur (Cömert \& Özkaya, 2014, s. 63). Kivela \& Crotts'a (2005, s. 41) göre; kavram 'iyi yiyecekleri seçme, hazırlama, servis etme ve bu yiyeceklerden zevk alma sanatı' șeklinde tanımlanmaktadır.

Birçok ülkede turizm gelirlerinin önemli bir kısmını sağlayan gastronomi turizmi, Türkiye'de de gelişim göstermesi beklenen bir alan konumundadır (Hatipoğlu, 2014, s. 25). Gastronomi turizmi açısından Türkiye, zengin mutfağıyla güçlü bir potansiyele sahip olmasına rağmen halen istenilen düzeyde rağbet görmemektedir. Bunun başlıca nedeni ülkemizin turizme yönelik pazarlama faaliyetlerinde ve özellikle tanıtımında halen deniz, kum, güneş üçlüsüne verilen ağırlıktır (Bucak ve Aracı, 2013, s. 207).

Gastronomi turizmi, hizmet ve deneyimlerin bir parçası olmasından dolayı mevcut turizm türleriyle birlikte geliștirilebilecek bir varış noktasıdır (Du Rand \& Heath, 2006, s. 209). Yerel yemek kültürleri, destinasyonların kültürel mirasları olarak değerlendirilmekle birlikte yerel yemekler, bir destinasyonun sahip olduğu en değerli çekiciliklerden biri olarak nitelendirilmektedir (McKercher, Okumuş \& Okumuș, 2008, s. 137). İşte bu nedenle gastronomi turizmi, tatil yörelerinin ve ilgi çekici mutfak kültürüne sahip yerlerin pazarlanmasında çekici bir unsur olarak kullanılabilir (Eren, 2011, s. 10).

Son yıllarda gastronomi turizminin gelişimi, yöre mutfağının sahip olduğu yöresel bir lezzetin, bir turizm ürününe dönüşmesi aşamasında olup, yörenin turizm gelirlerinde önemli bir etkiye sahip olabilmektedir (Göker, 2011, s. 48). Değișen turist profilleriyle 
birlikte gastronomi turizmi bölgeyi ziyaret eden turistlerin en önemli faaliyetlerinin bașında gelmeye başlamaktadır (Selwood, 2003, s. 179). Buna bağlı olarak, 2012 yılında "Dünya Turizm Örgütünün (UNWTO)" hazırladığı "Yemek Turizmi Küresel Raporu'na" göre turizm gelirleri açısından gastronomi turizminin diğer destinasyonlar içinde \%30 civarında bir paya sahip olduğu tahmin edilmektedir (Global Report on Food Tourism, 2012, s. 14).

Literatürde gastronomi turizmi açısından, Türkiye'yi ziyaret eden turistlerin, Türk mutfak kültürü ile ilgili görüşlerini araştıran çalışmalar mevcuttur. Örneğin, Özdemir \& Kınay (2004, s. 15) çalışmalarında, yabancı turistlerin \%87'sinin Türk yemeklerini beğendiklerini tespit etmişlerdir. Mankan (2012, s. 75) çalışmasında, turistlerin \%66,3'ünün Türk Mutfağını çok lezzetli bulduklarını ileri sürmektedir. Aynı şekilde Albayrak (2013, s. 5058) katılımcıların \%67,2'sinin yemekleri lezzetli buldukları sonucuna ulaşmıștır. Albayrak (2013, s. 5056) ayrıca katılımcıların \%96,6'sının ülkelerine döndüklerinde Türk yemeklerini tavsiye edeceklerini iddia etmektedir.

$\mathrm{Bu}$ değerlendirmelerden yola çıkılarak, gastronomi turizmi açısından Türk Mutfağı'nın özellikle coğrafi ișaret tescil belgesine sahip olan ve ayırt edici özellikleri ile ön plana çıkan yöresel lezzetlerinin pazarlanmasında ve özellikle tanıtımında izlenecek stratejilerin üst düzeyde olması ve profesyoneller tarafından yapılması gerektiği söylenebilir.

\subsection{Ankara'nın Coğrafi İşaretli Gastronomik Ürünleri}

Zengin iklim çeşitlerine sahip Türkiye'nin her yöresinde, yöreye özgü birbirinden farklı lezzetler bulunmaktadır. Bu yöresel lezzetlerin coğrafi işarete sahip olmaları için TPE'den tescil hakkının alınması gerekmektedir. Tablo 3'te Ankara'nın coğrafi işarete sahip olan gastronomik ürünlerine yer verilmiștir.

\begin{tabular}{|ll|c|c|c|c|}
\hline & Coğrafi İşaret Adı & Türü & $\begin{array}{c}\text { Başvurunun } \\
\text { Yapıldığı İl }\end{array}$ & Durumu & $\begin{array}{c}\text { Tescil } \\
\text { Yılı }\end{array}$ \\
\hline 1. & Ankara Döneri & $\begin{array}{c}\text { Mahreç } \\
\text { İşareti }\end{array}$ & Ankara & Tescilli & 2017 \\
\hline 2. & $\begin{array}{l}\text { Ankara Erkeç } \\
\text { Pastırması }\end{array}$ & Menşe Adı & Ankara & Tescilli & 2019 \\
\hline 3. & Ankara Simidi & $\begin{array}{c}\text { Mahreç } \\
\text { İşareti }\end{array}$ & Ankara & Tescilli & 2017 \\
\hline 4. & Ankara Tava & $\begin{array}{l}\text { Mahreç } \\
\text { İşareti }\end{array}$ & Ankara & Tescilli & 2017 \\
\hline 5. & Beypazarı Kurusu & $\begin{array}{c}\text { Mahreç } \\
\text { İşareti }\end{array}$ & Ankara & Tescilli & 2013 \\
\hline 6. & Çubuk Turşusu & $\begin{array}{l}\text { Mahreç } \\
\text { İşareti }\end{array}$ & Ankara & Tescilli & 2008 \\
\hline 7. & $\begin{array}{l}\text { Kalecik Karası } \\
\text { Üzümü }\end{array}$ & $\begin{array}{c}\text { Mahreç } \\
\text { Isşareti }\end{array}$ & Ankara & Tescilli & 2007 \\
\hline 8. & $\begin{array}{l}\text { Kızılcahamam } \\
\text { Bazlaması }\end{array}$ & $\begin{array}{c}\text { Mahreç } \\
\text { İșareti }\end{array}$ & Ankara & Tescilli & 2018 \\
\hline
\end{tabular}

Tablo 3: Ankara'nın Coğrafi İşaret Tesciline Sahip Gastronomik Ürünleri Kaynak: TPE, 2020.

Tablo 3'te görüldüğü gibi Ankara ilinin sahip olduğu coğrafi işaretli ürün sayısı 8 olup, bu ürünlerden sadece Ankara Erkeç Pastırması menşe adı ile tescillenmiştir. 


\subsection{Beypazarı ve Beypazarı Kurusu}

Beypazarı ilçesi, Ankara ilinin kuzeybatısında bulunmaktadır ve Ankara'ya uzaklığı 98 kilometredir. İlçe, Eski İpek Yolu güzergâhı üzerinde bulunan AnkaraAdapazarı-İstanbul yolu üzerindedir. Doğusunda Ayaş, Güdül ve Çamlıdere, batısında Nallıhan, kuzeyinde Bolu'nun Kıbrısçık ve Seben ilçeleri, güneyinde ise Polatlı bulunmaktadır.

Geçmişten günümüze birçok medeniyete ev sahipliği yapmış Beypazarı, tarihi ve kültürel zenginliklerle birlikte yöresel lezzetlere de sahiptir. Anadolu'nun lezzetlerini içerisinde barındıran Beypazarı yemekleri, sunumunun inceliği ve zarafetinden dolayı "İnce Takım" olarak adlandırılmaktadır. Beypazarı, el yapımı tarhana çorbası, taş fırınlarda pişirilen ve özel güveçlerde ikram edilen etli güveci, parmak kalınlığında damarsız ve ince kara üzüm yaprağından yapılan etli dolması, 80 kat ince yufkadan hazırlanan baklavası ve yöresel bir tatlısı olan höşmerimiyle zengin bir mutfağa sahiptir (T.C. Beypazarı Belediyesi, 2018). Beypazarı'ndaki yöresel yemek kültürünün zengin olmasının en önemli sebebi ilçede aktif olarak tarım yapılması ve dolayısıyla ürün çeşitliliğine sahip olunmasıdır. Verimli topraklara sahip olan ilçede, nüfusun yarıdan fazlası tarımla uğraşmaktadır. Beypazarı birçok büyük şehrin domates, ıspanak, havuç gibi sebze ihtiyacını karşılamaktadır. Türkiye'deki havuç ihtiyacının \%60'ını kendi başına Beypazarı karşılamaktadır. Yöresel ürün olarak havuç suyu, lokumu ve reçeli de ilçede yetişen havuçtan yapılır ve en değerli yerel ürünlerdendir. Yörede yetiştirilen üzümlerden pekmez ve cevizli sucuk yapılmaktadır. Her yıl geleneksel olarak düzenlenen Havuç ve Güveç Festivali'nde yöresel yemek yarışmaları düzenlenmektedir (T.C. Beypazarı Kaymakamlığı, 2018).

Türk Mutfağı içerisinde Beypazarı'nın kendine has Beypazarı Güveci, Beypazarı Dolması, 80 Kat Baklavası ve coğrafi işaret tescil belgesine sahip olan Beypazarı Kurusu gibi yerel ürünleri vardır. Beypazarı Kurusu yörenin en meşhur lezzetlerinden biridir. Beypazarı Kurusunun tarihçesi ile ilgili kesin bilgiler bulunmamakla beraber kuru üretiminin en az 100 yıllık geçmișe sahip olabileceği iddia edilmekte, hatta Çanakkale Savaşı'nda askerlere azık olarak dağıtıldığı söylenmektedir (Taşdan vd., 2014, s. 1296). Beypazarı Kurusu parmak büyüklügünde olup un, süt ve yağdan yapılarak bir sene saklanabilmektedir. Besleyici ve doyurucu bir özelliğe sahip olan kurunun hazım kolaylığ ve uzun süre tazeliğini koruma özelliği vardır. Üretimde kullanılan un, sert buğdaydan elde edilen ekmeklik olarak isimlendirilen undur. Süt, günlük olmakla birlikte sağıldıktan sonra bekletilmeden işlenmeye başlanmaktadır. Kendine has bir lezzete sahip olan Beypazarı Kurusunun coğrafi işaret tescil belgesi, 2009 yılında yapılan başvurunun 2012 yılında sonuçlanması ile Beypazarı Ticaret Odası tarafından alınmıştır (Türk Patent Enstitüsü, 2012).

\section{Yöntem}

Araştırmanın amacı, coğrafi işaret tescil belgesine sahip olan Beypazarı Kurusu üreticilerinin yaşadıkları sorunları, meslek ile ilgili gelecekteki beklentilerini, coğrafi işaret tescil belgesinin satış durumlarına etkisinin olup olmadığını ve çırak yetiştirme durumuna bağlı olarak gelecek yıllarda Beypazarı Kurusunun varlığını sürdürüp sürdüremeyeceğini ortaya çıkarmaktır. Bu amaçla nitel araştırma desenlerinden durum (örnek olay) çalışması kullanılarak, çalışmaya konu olan ortam ve olaylar, kendi gerçek yaşam çerçevesinde bütüncül olarak yorumlanacaktır (Yıldırım \& Şimşek, 2008: 278).

Araştırmada nitel araştırma yöntemlerinden derinlemesine görüşme tekniği kullanılmıştır. Nitel araştırma gözlem, görüşme ve dokümanların analizi gibi veri toplama tekniklerinin kullanıldığı bir araştırma süreci olarak tanımlanmaktadır (Yıldırım \& 
Şimşek, 2008, s. 39). Derinlemesine görüşme tekniği, araştırılacak olan konunun bütün boyutlarını detaylı bir şekilde kapsayan, açık uçlu sorulara yer verilen, yüz yüze gerçekleștirilen ve daha detaylı cevapların alınmasını sağlayan bir yöntemdir (Tekin, 2006, s. 101).

Araştırmada, önceden hazırlanan 16 sorudan oluşan ve gerekli durumlarda ilave sorular sorulan yarı yapılandırılmış görüşme formu kullanılmıştır. 16 sorudan 3'ü katılımcıların demografiklerini, 2'si ise tanımlayıcı istatistiklerini belirlemeye yöneliktir. Görüşme sorularının belirlenmesinde sektör ve akademiden uzman kişilerin görüşlerinden ve Köroğlu'nun (2013) çalışmasından yararlanılmıștır. 30 ila 60 dakika süren görüşmelerde, katılımcıların sorulara verdikleri cevaplar, katılımcıların izinleri alınarak ses kayıt cihazına kaydedilmiştir.

Araştırma, Ankara ili Beypazarı ilçesinde gerçekleştirilmiştir. Beypazarı Ticaret Odası'ndan alınan bilgiye göre, Beypazarı'nda toplamda 13 adet kuru imalatçısı bulunmaktadır. 13 adet kuru imalatçısından 9 tanesi resmi olarak kuru imalatı üreticisi olarak kayıtlı iken, diğer 4 firma unlu mamuller işletmesi olarak kayıtlıdır. Araştırma, Beypazarı Ticaret Odası'na kuru imalatçısı olarak kayıtlı olan 9 üreticiden mali ve zaman kısıtlılığı nedeniyle ve üreticilerin yoğun olmasından dolayı 7 üretici ile görüşülerek gerçekleştirilmiştir. Tamsayım yapılamadığından, sonuçlar genellenemez ancak genel hakkında fikir verebilir. Bulgular tematik kategoriler üzerinden açıklanmış ve bulguların sunumunda "kısa olma" ve zengin veri içerme" özelliklerine odaklanılmıştır (Başfırıncı, 2011, s. 121).

\section{Bulgular}

\subsection{Katılımcıların Demografik Bilgileri}

Araştırmaya Ankara ilinin Beypazarı ilçesinde kuru imalatı yapan 7 üretici katılmıştır. Araştırmaya katılan katılımcıların kişisel bilgilerinin korunması amacı ile isimleri kullanılmayarak, her bir katılımcı 1'den 7'e kadar (K1-K7) sırasıyla kodlamıștır. Katılımcıların demografik ve tanımlayıcı özellikleri Tablo 4'te görülmektedir. Katılımcıların 6'sı erkek 1'i kadın olup, 5'i lise, 1'i ortaokul ve 1'i lisans mezunudur. Araştırmaya katılan katılımcılardan en yüksek deneyime sahip olan K5 iken, en düşük deneyime sahip olan K6'dır. Katılımcıların yarıdan fazlası (4) mesleği ustalarından öğrenmişlerdir.

\begin{tabular}{|c|c|c|c|c|c|}
\hline Katılımcılar & Cinsiyet & Yaş & Eğitim & Deneyim & $\begin{array}{c}\text { Mesleği Kimden } \\
\text { Ögrendiği }\end{array}$ \\
\hline K1 & Erkek & 36 & Lise & 12 yll & Ailesinden \\
\hline K2 & Erkek & 60 & Lise & 14 yll & Kendisi \\
\hline K3 & Erkek & 39 & Lisans & 6 yıl & Kendisi \\
\hline K4 & Erkek & 31 & Ortaokul & 8 yll & Ustalarından \\
\hline K5 & Erkek & 40 & Lise & 21 yll & Ustalarından \\
\hline K6 & Kadın & 49 & Lise & 5 yll & Ustalarından \\
\hline K7 & Erkek & 23 & Lise & 8 yıl & Ustalarından \\
\hline
\end{tabular}

Tablo 4: Katılımcıların Demografik ve Tanımlayıcı Bilgileri

\subsection{Beypazarı Kurusunun Geleceğine Yönelik Beklentiler}

Araştırmaya katılan katılımcılara Beypazarı Kurusunun geleceğine yönelik beklentileri sorulduğunda; K1“Beklenti büyük. Türkiye'de hemen hemen tanımayan 
yoktur. Daha çok tanınır olmasını ve yurt dışına satışının olmasını, güzelliğinin bozulmaması ve standartları dâhilinde yapılmasını istiyoruz" demiş, K2 "Amaçlarının dünyaya tanıtmak" olduğunu söylemiștir. K4 beklentilerinin "Ülkenin her yerine yayılması" olduğunu belirtirken, K6 ise "Daha çok beğenilip iyi yerlere gelmesi" olarak ifade etmiştir. K3 "Zamanla fabrikasyona döneceğini" belirtirken, K5 "Kullanılan malzemelerin maliyetinin artması ile kuru üretiminde farklı malzemeler kullanılıyor ve bu durum özelliğinin bozulmasına sebep oluyor. Maliyetlerin azalmasını bekliyoruz. Maliyet düşmezse kurunun özelliği bozuluyor. Bu da satışları etkiliyor" demiștir. K7 ise "Beypazarı Kurusunun imalatında çalışacak çıraklar, elemanlar yetişmediğinden ilerisi için fazla bir gelecek göremiyorum" diye ifade etmiştir.

\subsection{Beypazarı Kurusu Üretiminde Çalıșan Elemanlarda Aranan Nitelikler}

Araştırmaya katılan bütün katılımcılar, elemanlarda aranan nitelikler konusunda hemfikir olup; bu niteliklerin el çabukluğu, hamur bilgisi, hamuru kesme işlemini bilmesi, temiz ve titiz olunması ve hijyen belgesine sahip olunması șeklinde sıralamışlardır.

\subsection{Beypazarı Kurusunun Satış Durumuna Yönelik Değerlendirmeler}

Katılımcılara satış durumuna yönelik düşüncüleri sorulduğuna; K1 “ Beypazarı́na gelen herkes nerdeyse kuru alıp gider. Ne kadar çok turist gelirse o kadar satış olur" diye ifade ederken, K2 "Ürün kaliteli olursa daima satılıyor. Kaliteden ödün verilirse satılmaz" demiștir. K3 “Günden güne artarak ilerlemektedir" görüşünü ifade etmiş, K4 "Satışlar iyi, gelecekte daha iyi olacaktır" diye belirtmiștir. K5 "Turistler geldiği için iyi fakat dışarıya iyice yayılması lazım" olarak ifade ederken, K6 "Daha çok kesime ulaştırabilirsek ne mutlu bize" olarak görüşünü bildirmiştir. K7 ise "Son 1-1,5 yıldır yavaş. Hammaddelere zam geldi fiyat arttı" ifadelerini kullanmıștır.

\subsection{Beypazarı Kurusunun Üretimi ile İlgili Yeni Teknikler Geliștirilmesi}

Araştırmaya katılan katılımcılardan K1, K2, K3, K4, K5 Beypazarı Kurusunun özgün kalması gerektiğini, K6 ve K7 ise sipariş isteğine göre susamlı, çörek otlu Beypazarı Kurusu ürettiklerini belirtmişlerdir.

\subsection{Kuru Mesleğinin Geleceğine Yönelik Beklentiler}

Katılımcılara mesleğin daha iyi yerlere gelmesi konusunda beklentileri sorulduğunda K1 "Ticaret odası ve belediye yanımızda, her zaman destekçimiz. Her daim bu kurumlar yanımızda olduğu sürece, kuru mesleği daha iyi yerlere gelecektir", K2 "Doğallığının bozulmadan üretimi arttırılması", K3 "El işçiliğini azaltıp, otomasyona geçerek fabrika üretimine geçilmesi gerekir", K4 ise "Bence iyi bir noktada meslek" diye belirtmişlerdir. K5 "Daha çok tanıtımı yapılmalı ve yaygınlaştırılmalı" diye ifade ederken, K6 "Mesleğe daha çok imkân tanınmalı" diye görüş bildirmiştir. K7 ise "Çalışan elemanlara, ustalara daha iyi ücret sağlanarak iyi noktalara gelinebilir. Ustalar Ankara'da daha iyi maaş imkânına sahip olduğu için kuru işini bırakıp pastacılığa geçiyor" diye ifade etmiştir.

\section{7. Üretimde Kullanılan Malzeme Temini}

Katılımcılardan K1, K3, K4, K5 ve K6 kuru yapımında kullanılan sütün Beypazarı'ndan alındığını, tereyağı ve unun dışarıdan geldiğini belirtmişlerdir. K2 ve K7 
ise süt ve tereyağının Beypazarı'ndan satın alındığını, diğer ürünlerin dışarıdan getirildiğini ifade etmişlerdir.

\subsection{Beypazarı Kurusu İmalatından Başka Bir İşe Sahip Olunup Olunmaması}

$\mathrm{K} 2$, K4, K5 ve K6 bașka bir iş ile uğraşmadıklarını, K3 ve K7 ise diğer yöresel ürünlerin üretilmesinde faaliyet gösterdiklerini belirtmişlerdir. K1 ise hayvancllık ve diğer yöresel ürünlerle ilgili bir ișe sahip olduğunu ifade etmiştir.

\subsection{Beypazarı Kurusu ile İlgili Karşılaşılan Sorunlar}

Araștırma katılımcılarından K1 "Toptan satışlarda, büyük marketlere satıșta sıkıntı var" diye belirtirken, K2 "Bazen tedarik edilen malzemeler kaliteli çıkmıyor. En çokta unda bu problemi yaşıyoruz. Üretimi olumsuz etkiliyor" demiştir. K3 "Personel sorunu" yaşadıklarını ifade etmiş, K5 "Kuru üreticisinin çoğalması ile kurunun özelliğinin bozulması" diye belirtmiştir. K7 "Şu an tedarikte sorun yaşıyoruz" diye görüşünü ifade ederken, K4 ve K6 ise herhangi bir sorun yaşamadıklarını belirtmişlerdir.

\subsection{0. Çırak Yetiştirme Durumu}

Katılımcılardan sadece K6 çırak yetiştirdiklerini ifade etmiştir. Diğer katılımcılar, genç neslin kuru mesleğine sıcak bakmadığını ve çırak bulmakta zorluk çektiklerini belirtmişlerdir. Ayrıca, genç neslin mesleğe kazandırılması konusunda K1 "Beypazarı'nda bulunan meslek yüksekokulunda ve meslek liselerinde fırıncılığın bir dalı olması gerekir" diye görüş bildirmiştir.

\subsection{Beypazarı Kurusunun Coğrafi İșaret Tescil Belgesine Sahip Olmasının Yerel Ekonomiye Katkı Sağlayıp Sağlamadığı}

K2, K4, K5 ve K6 yerel ekonomiye katkı sağladığını söylerken, K1 ise "Şu anda çok bir katkısı olduğunu sanmıyorum ama ileride daha iyi olacak" diye belirtmiştir. K7 "İlk başlarda iyiydi fakat sonradan işler durakladı. Fazla bir katkı sağlamadı" diye ifade etmiş, $\mathrm{K} 3$ ise "Tam takipçisi olunamıyor. Başka yerlerde kaçak çalışan işletmeler var. Bunların engellenmesi gerekiyor" şeklinde görüş bildirmiştir.

\section{Olmadığı \\ 5.12. Coğrafi İşaret Tescil Belgesi Alındıktan Sonra Satışlarda Artış Olup}

Katılımcılardan K1, K6 ve K7 satışlarda artış olduğunu, K2 ve K5 hemen hemen aynı olduğunu ifade etmişlerdir. K4 biraz artış olduğunu, K3 ise herhangi bir artış olmadığını belirtmiștir.

\section{Sonuç ve Tartışma}

Gerek iklimin gerek coğrafi şartların sunduğu imkânlar Anadolu coğrafyasının çeşitli medeniyetlere ev sahipliği yapmasının en temel sebebidir. Birçok medeniyetin yaşadığı Türkiye sınırları içerisinde, coğrafi șartların iyi olması ve çeșitli iklimlere sahip olunması ile birlikte birçok kültür birleşerek, Türkiye'nin 7 bölgesinde birçok yöresel lezzetlerin oluşmasını sağlamıştır. $\mathrm{Bu}$ bölgelere has yöresel ürünlerin turizm endüstrisinde kullanılması, hem bölge halkının istihdamı ve kalkınması hem de bölge tanıtımı ve kent markalaşması bağlamında önem arz etmektedir. 
Ankara ilinin Beypazarı ilçesi, kendine özgü birçok yöresel lezzete sahiptir. Bu yöresel lezzetlerden biri de coğrafi işarete sahip Beypazarı Kurusudur. Çalışmada nitel bir araştırma ile gastronomik bir ürün olarak Beypazarı Kurusunun, meslek ve sektör bağlamında sürdürülebilirliği üreticileri gözünden değerlendirilmiştir. Derinlemesine görüşme tekniğinin kullanıldığı araştırmaya, Beypazarı Ticaret Odası'na kayıtlı 9 imalatçıdan 7'si ile katılmıştır. Katılımcılardan sadece 1'inin kadın olduğu görülmektedir. Tatar \& Armatlı Köroğlu (2017) çalışmalarında Beypazarı'nda kırsal turizmin gelişmesi ile kadınların yüksek oranda iş hayatına katıldıklarını tespit etmişlerdir. Altunöz Sürücü, Kargiglioğlu \& Ak'ın (2017) çalışmalarında belirtmiş oldukları gibi Beypazarı Belediyesi ve Kaymakamlığı geçmişte kadınlara yönelik yöresel ipek kilim dokuma, gümüşçülük gibi çeşitli seminer ve kurslar düzenleyip atölyeler kurarak, yöre kadınlarının turizm sektörü içerisinde yer almalarına yardımcı olmuşlardır. Gelecekte benzer şekilde, bir proje kapsamında veya halk eğitim merkezlerinde verilecek eğitimlerle yöre halkı kadınları kuru imalatına teşvik edilerek, hem Beypazarı Kurusunun sürdürülebilirliğine katkı sağlanabilir hem de yöre halkı kadınları için istihdam yaratılabilir.

Katılımcllara göre Beypazarı Kurusu üretimi faaliyetlerinde karşılaşılan sorunlar özetle, kalifiye personel eksikliği, üretim malzeme kalitesi ve tedarikindeki zorluklar, malzeme maliyetlerinin yüksekliği, çalışanlara verilen düşük maaş, ürünün tanıtımındaki eksiklikler ve bu nedenle pazar payının düşüklügüdür.

Gerek Beypazarı ilçesinin gerekse Beypazarı Kurusunun tanıtımı ile ilgili eksikliklerin giderilmesinde, ilçenin tarihi ve kültürel yapısı ile gastronomik ürünlerinin bir arada tanıtımlarının yapılarak, kent markalaşmasının oluşturulmasına yönelik pazarlama faaliyetleri gerçekleştirilebilir. Bu durum üstelik ilçeye gelen turist sayında ve dolayısıyla yöresel ürünlerin satışında artışa neden olarak, bölge ekonomisine de katkı sağlayacaktır. Coğrafi ișaretli ürünlerin bilinirliğini literatürce sınırlı iken (Çakaloğlu \& Çağatay, 2017; Keskin, 2019; Toprak \& Oğuz, 2017), coğrafi işaretli ürünlerin tanıtımına yönelik izlenecek stratejiler, bu ürünlerin bilinirliğine de hizmet edecektir. Kısacası, Türkiye'nin sahip olduğu yöresel lezzetlere sadece coğrafi işaret verilmekle kalınmayıp, bu ürünlerin tanıtımının da en iyi şekilde yapılması gerekmektedir.

Beypazarı Kurusu coğrafi işarete sahip olmasına rağmen katılımcılardan alınan bilgilere göre geleceği tehlike altındadır. Bu tehlikenin en büyük nedenlerinden biri kuru imalatçılarının çırak yetiştirememe durumudur. Bu durum gelecek yıllarda yöresel bir lezzet olan kurunun son bulmasına neden olabilir. Keza katılımcıların hepsi mesleği ya ailesinden, ya kendi kendine ya da ustalarından öğrenmişlerdir. Hazırlanacak meslek edinme ve eğitim projeleri ile üreticilerin çırak yetiştirme ve bulma sorununa da çözüm bulunabilir. Ayrıca, Beypazarı Kurusu üretiminin sürdürülebilirliğini sağlamak için Beypazarı'nda bulunan meslek liseleri ve meslek yüksekokullarında ilgili bölümler açılarak, hem eğitim sorununa çözüm bulunabilir hem de yöre gençleri bu alana yönlendirilebilir.

Katılımcıların büyük ölçüde Beypazarı Kurusunun sürdürülebilirliğine ilişkin mevcut ve gelecek tahmini satışlarına yönelik olumlu beklentilere sahip; yeni üretim tekniklerine, otomasyona ve ürün çeșitlenmesine ise kapalı oldukları görülmektedir. Beypazarı Kurusunun fabrika yöntemiyle üretiminin yapılması, özgünlüğünü yitirmesi endişesinden dolayı, sıcak bakılmayan bir konudur. Kuru üretiminin el ile yapılmasının mevcut istihdama katkısı da oldukça yüksektir (Taşdan vd., 2014, s. 1296).

Araştırmada ayrıca Beypazarı Kurusunun coğrafi işaret tescil belgesine sahip olmasının yerel ekonomiye sağladığı katkıya yönelik görüsşleri sorulduğunda, tam bir fikir birliğine rastlanamamakla birlikte, katılımcıların çoğunluğu olumlu yönde görüş bildirmişlerdir. Söz konusu belgenin satışlara etkisine yönelik ise benzer şekilde 7 katılımcıdan 4'ü satışlarda artış olduğunu diğer 3'ü ise herhangi bir artış olmadığını dile getirmișlerdir. Dolayısıyla literatürde olduğu gibi (Kan, 2011; Mercan \& Üzülmez, 2014; 
Orhan, 2010), Beypazarı Kurusunun coğrafi işaret tescil belgesi almasının genel olarak yerel ekonomiye fayda sağladığı söylenebilir. Bu bağlamda, gelecekte Beypazarı'nın diğer yöresel lezzetleri için de ilgili kurumlar tarafından coğrafi işaret tescil belgesine başvurulup tescil hakları alınarak hem ilçenin tanıtımına hem de yöre ekonomisine katkı sağlanabilir.

Bu çalıșmada coğrafi işaretli Beypazarı Kurusunun gastronomik bir ürün olarak, üreticiler nezdinde sürdürülebilirliği ile üreticilere ve yöreye sağladığg ekonomik katkısı değerlendirilmiştir. Çalışmanın en önemli kısıtı, kullanılan tekniğin ve örneklemin genellemeye izin vermemesi olup, bu kısıt gelecekte farklı teknikler benimsenerek ve tamsayıma gidilerek bertaraf edilebilir. Gelecekte tüketiciler üzerinde bir araștırma gerçekleştirilerek, Beypazarı Kurusuna yönelik tüketicilerin coğrafi işaret bilinirliğini, ürün değerlendirmeleri, ürüne yönelik tutum ve eğilimleri çalışılabilir. Beypazarı'nın diğer yöresel ürünleri, coğrafi işaret belgesine sahip olduktan sonra bölgeye gastronomi turizmi için gelen turist sayılarındaki artış ve yöreye sağladığı ekonomik katkılar incelenebilir. Ayrıca, gastronomi turizmi için Beypazarı'nı ziyaret eden turistlerin yöre mutfağı ve ürünlerine dair görüşleri ve tutumları araştırılarak, yöre mutfağının geliştirilmesine katkı sağlanabilir. Gelecekte benzer bir çalışma gerçekleştirilerek, mevcut ve gelecek durum karşılaștırılabilir.

\section{KAYNAKÇA}

ACAR, Y. (2018). Türkiye'deki coğrafi işaretli ürünlerin destinasyon markalanması kapsamında değerlendirilmesi. Journal of Tourism and Gastronomy Studies. Cilt 6 (2), 163-177.

AKIN, E.B. (2006). Coğrafi işaret olarak tescil edilmiş Malatya kayısısının teknolojik özelliklerinin saptanması ve gıda güvenliği açısından araştırılması. Doktora tezi. Hacettepe Üniversitesi Fen Bilimleri Enstitüsü, Ankara.

ALBAYRAK, A. (2013). Farklı milletlerden turistlerin Türk mutfağına ilișkin görüşlerinin saptanması üzerine bir çalışma. Journal of Yaşar University. Cilt30(8), 50495063.

ALTUNÖZ SÜRÜCÜ, Ö., KARGİGLİĞLU, Ş. \& AK, S. (2017). Kırsal turizmde geleneksel kültürün yansıtılması ve kadın istihdamı: Beypazarı örneği. 1. International Sustainable Tourism Congress Proceedings Books. 550-565. Kastamonu.

ALTUNTAŞ, A.,GÜLÇUBUK, B. (2014). Yerel kalkınmada yaygınlaşan bir araç olarak geleneksel gıdalar ve geleneksel gıda mevzuatınınyaygınlaştırılabilirliği. Gaziosmanpaşa Üniversitesi Ziraat Fakültesi Dergisi. Cilt 31 (3), 73-81.

ARIKAN, M. (2017). Türkiye'de coğrafi işaretli ürünlerin kırsal alana olan etkilerinin üretici açısından belirlenmesi: Finike portakalı örneği. Yüksek lisans tezi. Akdeniz Üniversitesi Fen Bilimleri Enstitüsü, Antalya.

BAȘFIRINCI, Ç. (2011). Modern Türk tüketim kültürüne yönelik bir araștırma. Milli Folklor Uluslararası Kültür Araştırmaları Dergisi. Cilt 12 (91), 115-129.

Beypazarı Ticaret Odası (2018). Tanıtım broşürü. Erişim: 28 Aralık 2018, http://www.beypazarito.org.tr/Dokuman/tanitim.pdf

BUCAK, T., ARACI, Ü. E. (2013). Türkiye'de gastronomi turizmi üzerine genel bir değerlendirme. Balıkesir Üniversitesi Sosyal Bilimler Enstitüsü Dergisi. Cilt 17 (30), 7-18.

BULUT, A. (2013). Coğrafi işaretler ve kırsal kalkınma: Ezine peyniri örneği.

Yüksek lisans tezi. Onsekiz Mart Üniversitesi Sosyal Bilimler Enstitüsü, Çanakkale. COŞKUN, A. Y. (2001). Coğrafi işaretler. Uzmanlık tezi. Türk Patent Enstitüsü, Ankara. 
CÖMERT, M.,ÖZKAYA, D. F. (2014). Gastronomi turizminde Türk mutfağının önemi. Journal of Tourism and Gastronomy Studies. Cilt 2 (2), 62-66.

ÇAKALOĞLU, M. (2015). Marka ürünler, coğrafi işaret ve tüketici algısı. Yüksek lisans tezi. Akdeniz Üniversitesi Sosyal Bilimler Enstitüsü, Antalya.

ÇAKALOĞLU, M.,ÇAĞATAY, S. (2017). Coğrafi işaretler ve değişen tüketici algısı: Finike portakalı ve Antalya tavşan yüreği zeytini örnekleri. Tarım Ekonomisi Araştırmaları Dergisi. Cilt 3 (1), 52-65.

ÇALIŞKAN, V.,KOÇ, H. (2012). Türkiye'de coğrafi işaretlerin dağılış özelliklerinin ve coğrafi işaret potansiyelinin değerlendirilmesi. Doğu Coğrafya Dergisi. Cilt 17 (28), 193-214.

DAYISOYLU, S. K., YÖRÜKOĞLU, T. \&ANÇEL, T. (2017). Kahramanmaraş'ın coğrafi işaretli ürünleri ve ilin potansiyel durumu. KSÜ Doğa Bilimleri Dergisi. Cilt 20 (1), 80-88.

DU RAND, G. E., HEATH, E. (2006). Towards a framework food tourism as an element of destination marketing. Current Issues in Tourism. Cilt 9(3), 206-234.

DURUSOY, Y. Y. (2017). Coğrafi işaretli gastronomik ürünlerin bölge halkı tarafından algılanması üzerine analitik bir araştırma: Kars kaşarı örneği. Doktora tezi. Haliç Üniversitesi Sosyal Bilimler Enstitüsü, İstanbul.

EREN, D. (2011). Alternatif bir turizm çeşidi olarak mutfak turizminin değerlendirilmesine ilişkin sektör temsilcilerinin görüşlerinin incelenmesi üzerine bir araştırma. Yüksek lisans tezi. Düzce Üniversitesi Sosyal Bilimler Enstitüsü, Düzce.

EROL, Y. (2014). Türkiye'de coğrafi işaretleme sisteminin mevcut yapısı. Yüksek lisans tezi. Gaziosmanpaşa Üniversitesi Fen Bilimleri Enstitüsü, Tokat.

GÖKER, G. (2011). Destinasyon çekicilik unsuru olarak gastronomi turizmi. Yüksek lisans tezi. Balıkesir Üniversitesi Sosyal Bilimler Enstitüsü, Balıkesir.

GÜNDEĞER, M. (2014). Coğrafi işaretlerin bölgesel turizm gelişimindeki önemi: Çanakkale ili örneği. Yüksek lisans tezi. Onsekiz Mart Üniversitesi Sosyal Bilimler Enstitüsü, Çanakkale.

GÜNDOĞDU, G. (2005). 555 Sayılı CoğIșKHK'nın uygulanmasında “ürün” kavramı ve bazı sorunlar. İstanbul Üniversitesi Hukuk Fakültesi Mecmuası. Cilt 62 (1-2), 213-238.

GÜNDOĞDU, G. (2006). Türk hukukunda coğrafi işaretler ve korunması. İstanbul: Beta Yayınları.

HATIPOĞLU, A. (2014). Osmanlı Saray Mutfağı'nın gastronomi turizmi çerçevesinde incelenmesi. Doktora tezi. Sakarya Üniversitesi Sosyal Bilimler Enstitüsü, Sakarya.

ILGAZ, D. (1995). Coğrafi işaretlerin korunması: Dünyada ve Türkiye'de durum. Marmara Üniversitesi Avrupa Topluluğu Enstitüsü Avrupa Araștırmaları Dergisi. Cilt 4 (1\&2), 117-142.

ILICALI, G. (2005). Coğrafi işaretler, coğrafi işaretlerde denetim ve denetimde akreditasyonun önemi. Ankara Üniversitesi Avrupa Toplulukları Araștırma Uygulama Merkezi, 36. Dönem Avrupa Birliği Temel Eğitim Programı Semineri, Ankara.

İLOĞLU, N. (2014). Coğrafi işaretlerin tescili ve denetimi üzerine farklı ülke sistemlerinin incelenmesi ve Türkiye uygulaması. Uzmanlık tezi. Türk Patent Enstitüsü Markalar Dairesi Başkanlığı, Ankara.

KAN, M. (2011). Yerel düzeyde ekonomik kalkınmada coğrafi işaretlerin kullanımı ve etkisi: Akşehir kirazı araştırması. Doktora tezi. Ankara Üniversitesi Fen Bilimleri Enstitüsü, Ankara.

KAN, M.,GÜLÇUBUK, B. (2008). Kırsal ekonominin canlanmasında ve yerel sahiplenmede coğrafi işaretler. Uludağ Üniversitesi Ziraat Fakültesi Dergisi. Cilt 22 (2), 57-66. 
KARAKULAK, Ç. (2016). Coğrafi işaretleme yoluyla gastronomik kimlik oluşturma ve gastronomik kimliğin destinasyon pazarlamasındaki rolü: Trakya örneği. Yüksek lisans tezi. Muğla Sıtkı Koçman Üniversitesi Sosyal Bilimler Enstitüsü, Muğla.

KAYA, Y. S., ŞAHIN, E. (2018). Tescilden Uygulamaya Coğrafi İşaretler: Adana kebabı üzerine bir inceleme. Güncel Turizm Araștırmaları Dergisi. Cilt 2 (Ek:1), 189-196.

KESKIN, H. (2019). Coğrafi işaretli yöresel gıdaların turistik destinasyon pazarlamasına etkileri- Balıkesir ili örneği. Yüksek lisans tezi. Balıkesir Üniversitesi Sosyal Bilimler Enstitüsü, Balıkesir.

KIVELA, J., CROTTS, J. C. (2005). Gastronomy tourism. Journal of Culinary Science \& Technology. Cilt 4 (2-3), 39-55.

KÖROĞLU, N. O. (2013). Çalgı yapım ustaları; Antalya ili örneği. Akademik Bakış Dergisi. 39, 1-9.

MANKAN, E. (2012). Yabancı turistlerin Türk Mutfağına ilişsin görüşleri: Ege Bölgesi örneği. Doktora tezi. Ankara Üniversitesi Fen Bilimleri Enstitüsü, Ankara.

MCKERCHER, B., OKUMUŞ, F. \& OKUMUŞ, B. (2008). Food tourism as a viable market segment: It's all how you cook the numbers. Journal of Travel \& Tourism Marketing. Cilt 25 (2), 137-148.

MENAPACE, L. (2010). Geographical indications and quality promotion in food and agricultural markets: Domestic and international issues. Ph.D. thesis. Lowa State University, Lowa.

MERAL, Y. (2013). Kahramanmaraş kent merkezinde coğrafi işaretli ürünlere ilişkin tüketici tercihleri: Gemlik zeytini örneği. Yüksek lisans tezi. Kahramanmaraş Sütçü İmam Üniversitesi Fen Bilimleri Enstitüsü, Kahramanmaraş.

MERAL, Y.,ŞAHİN, A. (2013). “Tüketicilerin coğrafi işaretli ürün algısı: Gemlik zeytini örneği”. Kahramanmaraş Sütçü Imam Üniversitesi Doğa Bilimleri Dergisi. Cilt 16 (4), 16-24.

MERCAN, O.Ş.,ÜZÜLMEZ, M. (2014). Coğrafi işaretlerin bölgesel turizm gelişimindeki önemi: Çanakkale ili örneği. Dokuz Eylül Üniversitesi İktisadi ve İdari Bilimler Fakültesi Dergisi. Cilt 29 (2), 67-94.

NORRSJÖ, L. G. (2004). Indications of geographical origin as part of the Intellectual Property Law. Master thesis. Stockholm Universitet, Stockholm.

OĞUZ, Z. (2016). Yerel değerlerin turizm ürününe dönüştürülmesinde coğrafi işaretlerin kullanımı: Siirt ili örneği. Yüksek lisans tezi. Mardin Artuklu Üniversitesi Sosyal Bilimler Enstitüsü, Mardin.

ORAMAN, Y. (2015). Türkiye'de coğrafi işaretli ürünler. Balkan ve Yakın Doğu Sosyal Bilimler Dergisi. Cilt 1 (1), 76-85.

ORHAN, A. (2010). Yerel değerlerin turizm ürününe dönüștürülmesinde 'Coğrafi İşaretlerin' kullanımı: İzmit pişmaniyesi örneği. Anatolia: Turizm Araştırmaları Dergisi. Cilt 21 (2), 243-254.

ÖZCAN, S. (2016). Coğrafi işaret kavramı ve Devrek bastonu örneği. Yüksek lisans tezi. Bartın Üniversitesi Fen Bilimleri Enstitüsü, Bartın.

ÖZDEMIR, B.,KINAY, F. (2004). Yabancı ziyaretçilerin Türk Mutfağına ilişkin görüşleri: Antalya'yı ziyaret eden Alman ve Rus turistler üzerine bir araştırma. Gazi Üniversitesi Ticaret ve Turizm Eğitim Fakültesi Dergisi. 2, 5-28.

ÖZGÜR, D. (2011). Coğrafi işaretlerin korunması: Avrupa Birliği'ndeki hukuki çerçeve ve Türkiye uygulaması. Doktora tezi. Dokuz Eylül Üniversitesi Sosyal Bilimler Enstitüsü, İzmir.

RANGNEKAR, D. (2003). A review of Proposals at the TRIPS Council:

ExtendingArticle 23 to productsotherthanWines and Spirits. Geographical Indications. 12 (39), 11-53. 
SELWOOD, J. (2003). The lure of food: Food as an attraction in destination marketing in Manitoba, Canada. In C.M. Hall, L. Sharples, R. Mitchell, N. Macionis \& B, Cambourne (eds.), Food tourism around the world: Development, Management, and Markets. 178-191. London: Butterworth Heinemann.

SUNA, B., UÇUK, C. (2018). Coğrafi işaret ile tescil edilmiş ürüne sahip olmanın destinasyon pazarlamasına etkisi. Journal of Tourism and Gastronomy Studies. Cilt 6 (3), 100-118.

ŞAHIN, A., MERAL, Y. (2012). Türkiye'de coğrafi işaretleme ve yöresel ürünler. Türk Bilimsel Derlemeler Dergisi. Cilt 5 (2), 88-92.

ŞAHINN, G. (2013). Coğrafi işaretlerin önemi ve Vize (Kırklareli)'nin coğrafi işaretleri. Pamukkale Üniversitesi Sosyal Bilimler Dergisi Enstitüsü. 15, 23-37.

ŞANLIER, N. (2005). Yerli ve yabancı turistlerin Türk mutfağı hakkındaki görüşleri. Gazi Eğitim Fakültesi Dergisi. Cilt 25(1), 213-227.

T.C. Beypazarı Belediyesi (2018). Yöresel yemekler. Geleneksel lezzetleriyle Beypazarı. Erișim: 28 Aralık 2018, http://www.beypazari.bel.tr/tr/sayfalar/yoreselyemekler-130

T.C. Beypazarı Kaymakamlığı (2018). Yöresel yemekler. Geleneksel lezzetleriyle Beypazarı. Erişim: 28 Aralık 2018,http://www.beypazari.gov.tr/yoresel-yemekler

TANRIKULU, M. (2011). Türkiye'de coğrafi işaretlerin tespiti ve tescil edilmesinin önemi. Uluslararası Sosyal Bilimler Eğitimi Dergisi. Cilt 1 (2), 173-184.

TAŞDAN, K., ALBAYRAK, M. \&ALBAYRAK, K. (2014, Samsun). Coğrafi işaret tescili geleneksel ürünlerde izlenebilirlik: Ankara ili örneği. XI. Ulusal Tarım Ekonomisi Kongresi, 3-5 Eylül 2014, Samsun.

TATAR, F., ARMATLI KÖROĞLU, B. (2017). Ankara ili Beypazarı ilçesi kırsal turizm gelişimi ve yerel kalkınmaya etkisi. Planlama Dergisi. Cilt 27 (2), 115-128.

TEKIN, H. H. (2006). Nitel araştırma yönteminin bir veri toplama tekniği olarak derinlemesine görüşme. İstanbul Üniversitesi Sosyoloji Dergisi. Cilt 3 (13), 101-116.

TEPE, S. (2008). Coğrafi işaretlerin ekonomik etkileri. Uzmanlık tezi. Türk Patent Enstitüsü Markalar Dairesi Bașkanlığı, Ankara.

TOPRAK, L., OĞUZ, Z. (2017). Coğrafi işaretler ve Siirt ili örneği. 18. Ulusal Turizm Kongresi. 964-973. Mardin.

TÖRE BAŞAT, H., SANDIKÇI, M., \&ÇELİK, S. (2017). Gastronomik kimlik oluşturmada yöresel ürünlerin rolü: Ürünlerin satış ve pazarlanmasına yönelik bir örnek olay incelemesi. Journal of Tourism and Gastronomy Studies. Cilt 5 (Special 2), 64-76.

Türk Patent Enstitüsü (TPE) (2012). Beypazarı kurusu coğrafi işaret tescil belgesi. Erişim: 28 Aralık 2018, http://www.turkpatent.gov.tr/TURKPATENT/resources/temp/050FC266-A26B-452A80A3-0108BFE24C36.pdf

Türk Patent Enstitüsü (TPE) (2020). Coğrafi işaret ve geleneksel ürün adı istatistikleri. Tescilli coğrafi işaretler. Erişim: 19 Temmuz 2020,

http://www.turkpatent.gov.tr/TURKPATENT/geopraphicalRegisteredlist/

Türk Patent Enstitüsü (TPE) (2018). Ulusal coğrafi işaret strateji belgesi ve eylem planı. Erişim: 29 Aralık 2018, http://www.turkpatent.gov.tr/TURKPATENT/resources/temp/5D1DDECD-C004-417586B4-1BA236F79059.pdf

TUNA, M., ÖZYURT, B.(2018). Ankara'da gastronomi turizminin değerlendirilmesi: Nitel bir araștırma. Journal of Tourism And Gastronomy Studies. Cilt 6 (3), 73-87.

TUNCAY, M. (2009). Coğrafi işaretlerin korunması. Yüksek lisans tezi. Kırıkkale Üniversitesi Sosyal Bilimler Enstitüsü, Kırıkkale. 
UNWTO (2012). Global report on food tourism. Erișim: 28 Aralık 2018,http://cf.cdn.unwto.org/sites/all/files/pdf/food_tourism_report.pdf

VAN DE KOP, P., SAUTIER, D. (2006). Origin-based products lesson for pro-poor market development. Bulletin. 372. 21-29.

YENIPINAR, U., KÖŞKER, H. \&KARACAOĞLU, S. (2014). Turizmde yerel yiyeceklerin önemi ve coğrafi ișaretleme: Van otlu peyniri. Journal of Tourism and Gastronomy Studies. Cilt 2 (2), 13-23.

YILDIRIM, A., ŞİMŞEK, H. (2008). Sosyal bilimlerde nitel araştırma yöntemleri. Ankara: Seçkin Yayıncılık.

YÜREKLİ, D. (2015). Coğrafi işaretlerin tescili ve uygulama sürecindeki sonuçların analizi. Yüksek lisans tezi. Gazi Üniversitesi Eğitim Bilimleri Enstitüsü, Ankara.

ZULUĞ, A. (2010). Coğrafi işaretli gıdalara ilișkin tüketici tercihleri üzerine bir araştırma: İstanbul örneği. Doktora tezi. Ege Üniversitesi Fen Bilimleri Enstitüsü, İzmir.

\section{Summary}

Products with geographical indications that aim to preserve the distinctive features of products that are specific to a region and transfer them to future generations, play an important role in terms of economic development and promotion of cultural heritage. The increasing interest of consumers in local products, especially in recent years, requires that the products that are specific to a region have a certain standard in the production and sales processes by protecting them with a geographical indication.

Turkey hosted many civilizations throughout the history and thus the cultural diversity emerged in the region. There are many different regions with a variety of delicacies that are specific to each region of Turkey. 367 of these local tastes have geographical indication registration. At the same time, there are many applications made to the Turkish Patent Institute (TPE) for geographical indication registration, which have not yet been completed.

Every society in the world has its own culture and products inspired by that cultural structure. Geographical indications are used to express the connection between a local product and a country, vicinity or region (Yenipınar, Kössker \& Karacaoğlu, 2014, p. 14). Products with geographical indications are mentioned along with the names of the regions where they occur. These regions can be a village, town or city. Since these products are specific to the region, they cannot be produced in other regions (Çakaloğlu, 2015, p. 15).

Gastronomy tourism can be developed alongside existing tourism types as it consists of services and Experiences such as any other types of tourism (Du Rand \& Heath, 2006, $p$. 209). Local food cultures are considered as the cultural heritage of the destinations and local food is considered as one of the most valuable attractions a destination may offer (McKercher, Okumuş \& Okumus, 2008, p. 137). For this reason, gastronomy tourism can be used as an attractive element in the promotion of a destination with a cuisine culture (Eren, 2011, p. 10).

Based on these evaluations, it can be said that the strategies to be followed in the marketing of local food, which have a geographical indication registration certificate, and which stand out with their distinctive features, should be run by professionals.

Beypazarl, which has hosted many civilizations from past to present, has local delicacies along with historical and cultural richness. In Turkish cuisine, Beypazarı has its own local products such as Beypazarı Casserole, Beypazarı Stuffing, Eighty Feuilles Baklava (a dessert with dough in the structure of mille feuilles) and Beypazarı Kuru, which has a geographical sign registration certificate. Beypazarl Kuru is one of the most famous tastes of the region. Although there is no definite information about the history of Beypazarı Kuru, 
it is claimed that the production may have a history of at least 100 years, even it is said to have been distributed to soldiers in the Battle of Dardanelles (Taşdan et al., 2014, p. 1296). Beypazarl Kuru is finger-sized and can be made from flour, milk and oil and has a shelf-life of one year. It has a nutritious and satisfying feature, and it eases digestion and offer freshness for a long time.

The aim of the research is to reveal Beypazarı Kuru producers' problems and future expectations. On the other side, the effect of geographical indication on sales and the apprenticeship status in the profession is investigated. For this purpose, using the case study, one of the qualitative research patterns in which the environment and events that are the subject of the study will be interpreted as holistic within the framework of their real life (YIldırım \& Simşek, 2008: 278). In research interviews which is a qualitative research method, were made with the producers. In the research, a semi-structured interview form consisting of sixteen questions was used and additional questions were asked when necessary. Three of the questions are for determining the demographics of the participants and two of them are for the descriptive statistics. The opinions of experts from the sector and academy and the study of Köroğlu (2013) were used in determining the interview questions. During the interviews, which lasted for 30 to 60 minutes, the responses of the participants to the questions were recorded in the voice recorder, with the permission of the participants.

According to the participants, the problems encountered in the production of Beypazarı Kuru are briefly, lack of qualified personnel, difficulties in production material quality and supply, high material costs, low salary given to employees, deficiencies in the promotion of the product and therefore low market share. In the study, when the opinions about the Beypazarı Kuru regarding the contribution of the geographical indication registration certificate to the local economy were asked, a full consensus could not be found, but the majority of the participants expressed a positive opinion. On the other hand, four of seven participants stated that there was an increase in sales and the other three does not mention any increase. Therefore, it can be said that the Beypazarl Kuru received a geographical indication registration certificate benefited the local economy in general. In this context, for the other local tastes of Beypazarl in the future, it may contribute to both the promotion of the district and the local economy by applying the geographical sign registration certificate by the relevant institutions. 